\title{
Evaluation of Tribological Properties by Using Different Process Fluid by Test Ball on Disc
}

\section{Roman Licek}

Faculty of Mechanical Engineering, Department of Machining and Assembly, Technical University of Liberec, Studentska 2, 46117 Liberec 1, Czech Republic. E-mail: roman.licek@tul.cz.

\begin{abstract}
Manufacture of new parts of machineries, devices, etc., especially in engineering and metallurgy requires machining of the feedstock in a mechanical way. During machining occurs immediate contact between the tested specimen and the tool and in their mutual relative movement of friction and wear. One of the possible variants how to eliminate this fact is the application of process fluids during machining.

Currently, we are trying to simulate long-term testing by laboratory testing called tribology. The experiment presents friction between two materials that are under real sliding contact. This article examines the tribological characteristics between two materials (tool - ball and workpiece material - disc). The paper contains findings when examining process fluids by tribological test Ball - on - disc, this test is currently used in practice, very widespread, this test can imitate various operations of cutting machining. This paper deals with the evaluation of tribological properties (the coefficient of friction, wear of disc and wear of ball) between the ball from ceramic material $\mathrm{Si}_{3} \mathrm{~N}_{4}$ and the test material (stainless steel X5CrNi18-10, EN 10088-3 and steel commonly used in engineering 16MnCr5, EN 10084-94) by using two kinds of process fluids.
\end{abstract}

Keywords: Tribology, steel, wear, coefficient of friction, lubricant

\section{Acknowledgment}

This paper is related to the investigation on the Specific University Research Projects, which are supported by the Ministry of Education (MSMT) of the Czech Republic.

\section{References}

[1] BAKAlOVA, T. et. al. (2015). Nanoadditives $\mathrm{SiO}_{2}$ and $\mathrm{TiO}_{2}$ in Process Fluids. Manufacturing technology. Ústí n. L.: J. E. Purkyne University in Usti nad Labem, 2015, Vol. 15, No. 4. p. 502 - 508. ISSN 1213-2489.

[2] BAKALOVA, T., VOLESKÝ, L., LOUDA, P., ANDRŠOVÁ, Z. (2014). The Use of Optical Microscopy to Evaluate the Tribological Properties. Manufacturing technology. 1. vyd. Ústí nad Labem: Faculty of Production Technology and Management, 2014, roč. 14, č. 3. S. 256 - 261. ISSN 1213-2489.

[3] STACHOWIAK, G., A. BATCHELOR. (2005). Engineering tribology. 3rd ed. Amsterdam: Elsevier ButterworthHeinemann, 2005, 801 s. ISBN 0- 7506 - 7836 - 4.

[4] BAKALOVA, T., LOUDA, P., VOLESKÝ, L., KŘIKLAVOVÁ, L. (2014). The Impact of Natural Nanoaditiv on the Tribological and Chemical Properties of Process Fluids. 8th INTERNATIONAL CONFERENCE ON TRIBOLOGY 30th October - 1st November 2014 SINAIA, ROMANIA. 1. vyd. Ploiesti: Ploiesti Publishing Hause, 2014. S. 143 - 148. ISBN 978-973-719-570-8.

[5] NEALE, M., J. (1995). The Tribology Handbook. 2nd ed. Amsterdam: Elsevier Butterworth-Heinemann, 1995, 582 s. ISBN $07-7506-1198-7$.

[6] STOLARSKI, T., A. (1995). Tribology in Machine Design Handbook. Amsterdam: Elsevier Butterworth-Heinemann, 1995, 311 s. ISBN 0-7506- 3623-8.

[7] POPOV, A., DUGIN, A. (2014). Study of reasons of increased active force using coolant with uncut chip thickness. International Journal of Advanced Manufacturing Technology. 2014. 70 (9-12), pp. 1555-1562.

[8] DUGIN, A., JERSAK, J., POPOV, A. (2014). Method for determining of the anti-adhesion ability of cutting fluids. Manufacturing Technology. 2014, 14 (2), pp. 145-149

[9] LIEMERT, G., DRÁBEK, F., ONDRA, O., VAVŘíK I. (1974). Obrábění, Praha 1974, 352 s., ISBN 04-231-74.

[10] VASILKO, K., (2009). Teória a praxe trieskového obrábania, vyd. Fakulta výrobných technológií Technicke univerzity v Košiciach, so sídlom v Prešove, 2009, 532 s, ISBN: 978-80-553-0152-5

[11] HUMÁR, A. TECHNOLOGIE OBRÁBĚNÍ- Studijní opory pro magisterskou formu Studia VUT- 1. Část

[12] JOKSCH, S. Evaluating the performance of water-misciblecutting fluids in tribotests and actual machining processes. Oemeta Chemische Werke GmbH, Uetersen, Germany. https://www.tapping-torque-test.com/files/5514/1233/8682/OEMETA_Evaluating_the_performance_of_water-miscible_cutting_fluid.pdf 